$4(31) / 2015$

\author{
Jolanta Bonar \\ Uniwersytet Łódzki \\ jolabonar00@poczta.onet.pl
}

\author{
Aleksandra Maj \\ Uniwersytet Łódzki \\ a.maj@uni.lodz.pl
}

\title{
Przedszkola Reggio Emilia we Włoszech miejscem rozkwitu dziecięcego potencjału
}

\section{Summary \\ Preschools in Reggio Emilia (Italy) a place where children's potential flourishes}

The article presents one of the most avant-garde educational experiences for young children in the world. The first preschools in Reggio Emilia (Italy) were established after the Second World War and they have been under the supervision of the municipality for over 45 years. The main initiator and educator of this early childhood practice was Loris Malaguzzi (1920-1994). One of the reasons for this long-lasting project is the readiness of Reggio Emilia educators to cross boundaries, and another is their openness to new ideas and perspectives. They take their inspiration not only from pedagogy, but from philosophy, the exact sciences, architecture, literature, and visual communication as well. Inspired by different ideas and theories, being reflective and inquiring, they interpret and construct their own concepts and theories instead of reproducing them.

Słowa kluczowe: edukacja przedszkolna, Reggio Emilia, codzienne życie w przedszkolu

Keywords: preschool education, Reggio Emilia, daily life in preschool

Reggio Emilia, 170-tysięczne miasto położone w regionie Emilia Romagna w północnych Włoszech, jest miejscem niezwykle prężnego systemu edukacyjnego dla małych dzieci, którego pierwsze placówki wczesnej edukacji zostały założone, a właściwie własnoręcznie wybudowane przez rodziców tuż po zakończeniu II wojny światowej. Siłami rodziców i nauczycieli od samego początku zarządzał wielki pedagog i myśliciel Loris Malaguzzi (1920-1994). Pierwsza placówka powstała w latach 1945-1947 w Villa Cella, głównie z inicjatywy organizacji kobiecych, które walczyły o równouprawnienie i prawo kobiet do pracy, jednocześnie jednak bardzo wysoko ceniły dzieci i dostrzegały potrzebę profesjonalnej opieki nad nimi. Już wówczas realizowano w niej działania, w których dziecko było przewodnikiem i pokazywało nauczycielowi to, czego można je nauczyć. Było podmiotem działań, partnerem w procesie edukacji. Te powojenne doświadczenia zaowocowały w 1963 roku, gdy również dzięki ruchowi kobiet, które rozwinęły pomysł 
traktowania przedszkoli jako miejsca publicznego, powstała pierwsza miejska placówka przeznaczona dla dzieci w wieku od 3 do 6 lat ${ }^{1}$. Zapoczątkowała ona półwiecze niezwykle wartościowych edukacyjnych doświadczeń w Reggio Emilia. Amerykański psycholog Howard Gardner, aby pokazać skalę osiągnięć eksperymentu, zestawia ją z historią amerykańskiej edukacji progresywnej, gdzie, tak jak w większości krajów (a inaczej niż w Reggio Emilia), teoretycznie tworzone ideały i wzorce rzadko bywają wykorzystywane w praktyce.

System Reggio można zwięźle opisać jako zbiór placówek dla małych dzieci, w których intelektualny, emocjonalny, społeczny i moralny potencjał każdego dziecka jest pielęgnowany i wzmacniany. Najważniejsza edukacyjna machina angażuje najmłodszych w długoterminowe projekty, prowadzone w pięknym, zdrowym i pełnym miłości otoczeniu. Dewey pisał o edukacji progresywnej przez dekady, ale jego szkoła istniała zaledwie przez 4 lata. [...] Nigdzie indziej na świecie nie ma takiej [jak w Reggio - przyp. A.M.] nierozerwalnej i symbiotycznej relacji pomiędzy progresywną filozofią szkoły i jej praktyką (Gardner 2012: vix $)^{2}$.

Taki sukces podejścia edukacyjnego Reggio możliwy był tylko dzięki kolektywnej mądrości: z jednej strony rodziców, z drugiej strony zaś pedagogów, którzy wspólnie występowali przeciwko zdradzie dziecięcego potencjału. Ciekawość, otwartość i gotowość do przekraczanie granic i łamania utartych schematów przyczyniły się do powstania unikatowego na skalę światową systemu miejskich placówek wczesnej edukacji, który obejmuje obecnie 12 żłobków (Nidi Comunali dell'Infanzia) i 22 przedszkola (Scuole Comunali dell'Infanzia $)^{3}$. W edukacyjnym świecie, przesiąkniętym praktykami normalizacyjnymi i opresyjnymi, w którym nieustająco dominuje dyskurs jakości wraz z językiem standardów i odpowiedzialności za ich osiągnięcie (zob. Dahlberg i in. 2013), tak odmienne doświadczenie, jakim jest system placówek wczesnej edukacji w Reggio Emilia, musiało wzbudzić ogromne międzynarodowe zainteresowanie. Do jego wzrostu przyczyniły się głównie dwa wydarzenia.

W 1991 roku grupa ekspertów, powołana przez amerykański Newsweek, uznała przedszkole Diana za najbardziej awangardową placówkę edukacyjną dla małych dzieci na świecie (Filipini, Vecchi 2006). Publikacja artykułu The 10 Best School in the World stała się iskrą, która rozbudziła niewyobrażalne zainteresowanie podejściem edukacyjnym Reggio Emilia, szczególnie wśród amerykańskich pedagogów. Drugim wydarzeniem, które spopularyzowało filozofię Reggio na ogromną skalę, była wystawa „Sto języków dziecka”, która ilustrowała projekty realizowane z małymi dziećmi w przedszkolach Reggio. Na przestrzeni 30 lat (1981-2011) zgromadziła ona na kilku kontynentach kilkaset tysięcy zwiedzających, którzy dzięki barwnym opisom i ilustracjom mogli poznać i zrozumieć istotę procesu uczenia się dzieci i nauczycieli w przedszkolach Reggio. Ponad-

1 Pierwszy miejski żłobek w Reggio Emilia został otworzony w roku 1971.

2 Wszystkich tłumaczeń z języka angielskiego dokonały autorki tekstu.

$3 \mathrm{http} / / /$ www.scuolenidi.re.it/allegati/contatti\%2069.pdf. 
to rokrocznie w organizowanych przez Reggio Children ${ }^{4}$ wizytach studyjnych w Reggio Emilia uczestniczy kilkuset badaczy i nauczycieli z całego świata, którzy osobiście pragną doświadczyć magii tego miejsca.

Co urzeka w placówkach wczesnej edukacji w Reggio Emilia najbardziej? Po wizycie w przedszkolach Reggio Jerome Bruner, niekwestionowany autorytet w zakresie psychologii poznawczej, napisał:

To, co uderzyło mnie w Reggio Emilia, to jak pielęgnowana jest tam wyobraźnia, przy jednoczesnym wzmacnianiu dziecięcego poczucia tego, co możliwe. [...] Pielęgnowanie wyobraźni jest rzeczą podstawową, nie wystarczy jednak tylko czytać bajki. To wyobraźnia jest tym, co ratuje nas przed oczywistym i banalnym, przed zwyczajnymi aspektami życia. Wyobraźnia przemienia fakty w przypuszczenia. Nawet cień rzucony na podłogę nie jest tylko cieniem: jest tajemnicą. Spróbuj go narysować, to zrozumiesz (Bruner 2012: xvii-xviii).

Doświadczenie, o którym pisał J. Bruner, możliwe jest jedynie w miejscu pełnym akceptacji dla kreatywności zarówno uczniów, jak i nauczycieli. Kreatywność dziecka rozkwita bowiem wtedy, jeśli obok niego jest kompetentny i kreatywny dorosły ${ }^{5}$. Proces tworzenia musi być rozpoznawany i uprawomocniany przez innych (zob. Bonar 2011).

To, co bez wątpienia zachwyca i urzeka w placówkach Reggio Emilia najbardziej, także autorki niniejszego tekstu, to ogromne zaufanie, jakim dorośli darzą dziecko. To wiara w dziecięcy potencjał i kompetencje oraz otwartość i gotowość podążania za dziecięcymi pomysłami, za ich subiektywnymi interpretacjami świata. L. Malaguzzi podkreślał:

Szkoła nie jest podobna do gry w bilard. Kiedy uderzasz bilę z odpowiednią siłą, uderza ona o stół i odbija się. Droga, jaką się potoczy, jest określona, w zależności od siły uderzenia i kierunku. Dzieci wcale nie są przewidywalne. Czasami szkoły funkcjonują tak, jakby były, ale są to szkoły bez radości (Malaguzzi 1994: 53).

Przedszkola Reggio Emilia są miejscem pełnym dziecięcej radości, miejscem, w którym nauczyciele w ścisłej współpracy z innymi dorosłymi, respektując potencjał i prawa wszystkich dzieci, organizują im jak najlepsze, z perspektywy społecznego konstrukcjoni-

\footnotetext{
${ }^{4}$ Reggio Children - Międzynarodowe Centrum do Obrony i Wspierania Potencjału i Praw Wszystkich Dzieci jest instytucją utworzoną w 1994 r. z inicjatywy Lorisa Malaguzziego. Jej głównym zadaniem jest organizowanie i prowadzenie przedsięwzięć mających na celu wymianę edukacyjno-kulturową pomiędzy doświadczeniem placówek wczesnej edukacji w Reggio Emilia a edukatorami i badaczami z całego świata. Zob. www.reggiochildren.it.

${ }^{5}$ Kreatywność nauczyciela jest tu rozumiana jako postawa wymagająca umiejętności obserwacji i interpretowania sposobów myślenia i działania dzieci, wrażliwości i otwartości na dziecięce obrazy świata, umiejętności stawiania pytań pozwalających poznać doświadczenie i wiedzę dzieci ich sposoby myślenia i strategie uczenia się oraz pytań stymulujących konflikt poznawczy, elastycznego planowania (otwartości na różnice, tolerancji rozbieżności, zdolności redefiniowania, giętkości myślenia, umiejętności myślenia pytajnego).
} 
zmu, warunki dla wspólnego uczenia się. Jak mówią same dzieci uczęszczające do przedszkoli w Reggio

Nasza skóra się różni, ale myśli nie.

Jeśli powiem mu wszystkie swoje myśli, to wtedy on zrozumie niektóre z nich, a ja zrozumiem jego.

W szkole uczymy się o rzeczach, których nie znamy, o ciele, o świecie (...) uczymy się myśleć zanim coś zrobimy, używać naszego umysłu, uczymy się jak się uczyć (...), uczymy się jak się bawić.

To prawo dzieci! (The Charter... 2002: 35).

U podstaw koncepcji wczesnej edukacji w Reggio Emilia leży oparta na założeniach społecznego konstrukcjonizmu w i z j a d z i e c k a: dziecka pełnego potencjału, którego źródłem jest dziecięca umiejętność dziwienia się; dziecka silnego i kompetentnego. Dziecko jest mocne od narodzin, otwarte na świat i zdolne do konstruowania wiedzy. Jego kompetencje od samego początku przejawiają się w interakcjach z innymi, w tworzeniu własnych teorii, w interpretowaniu rzeczywistości i nadawaniu temu, co doświadcza, różnych znaczeń. Dziecko jest zarówno posiadaczem, jak również konstruktorem praw. Wynika z nich bezwzględny szacunek dla jego tożsamości, odmienności i indywidualności (Rinaldi 1998). Wiedza z perspektywy społecznego konstrukcjonizmu nie jest absolutna i niezmienna, tak więc dziecko ma możliwość negocjowania i tworzenia alternatywnych konstrukcji zanim spotka się z konstrukcjami akceptowanymi przez naukę (Dahlberg i in. 2013).

Dziecko, postrzegane jako badacz i odkrywca (protagonista), współpracownik oraz uczestnik procesu komunikacji (Cadwell 2003), działa w przemyślanej i starannie zaprojektowanej przestrzeni, w której jego sto języków, jak określał różnorodne sposoby komunikowania się dziecka L. Malaguzzi, ma szansę zaistnieć. To właśnie p r ze str z eń e d u k a c y j n a, uważana za „trzeciego nauczyciela”, obok dwóch pracujących w każdej grupie, jest kolejnym elementem, który wyróżnia podejście Reggio Emilia. Na jej niezwykłość zwróciła również uwagę autorka artykułu opublikowanego w Newsweeku.

Oszklone przedszkole Diana w Reggio Emilia w północnych Włoszech wygląda raczej jak wesoła szklarnia niż publiczne przedszkole. Dziecięca sztuka jest wszędzie - na ścianach, namalowana na oknach, zwisająca z sufitów, rozłożona na stołach. Są tam ceramiczne płytki z konikami morskimi, ruchome modele ludzkich sylwetek zrobione z drutów i koralików oraz gliniane figurki drzew i liści. Dwie przebieralnie oferują kostiumy dla tych dzieci, które na jeden dzień chcą się za kogoś przebrać (Hinckle 1991: 52).

Już przy pierwszej wizycie w przedszkolach Reggio Emilia obserwator nie ma wątpliwości, że są one miejscem autentycznej twórczości, a nie miejscem reprodukowania i transmisji wiedzy (Rinaldi 2006). Projekt przedszkola jest wynikiem głębokiej refleksji i dialogu pomiędzy pedagogami, rodzicami i architektami. Główny korytarz prowadzi do centralnego miejsca w przedszkolu - placu (piazza), który wykorzystywany jest do grupowych zabaw, 
przedszkolnych uroczystości czy spotkań z rodzicami. Wokół niego rozlokowane są klasy, oddzielone szklanymi ścianami, które mają zapewniać poczucie wspólnoty. Szklane ściany, oddzielające wewnętrzny ogród, dostarczają naturalnego światła, które daje okazję do różnorodnych zabaw z cieniem i odbiciem. Klasy podzielone są na mniejsze przestrzenie, które umożliwiają efektywną pracę w małych grupach. W każdej klasie znajduje się kącik konstrukcyjny, mini atelier lub specjalnie zaadaptowane miejsce do zajęć plastycznych, miejsce do odpoczynku, skrzynki na listy, biblioteczka, miejsce do gier i zabaw (Gandini 2012a). O tym, jak ważną rolę w procesie konstruowania wiedzy przypisują edukatorzy Reggio Emilia wyobraźni, twórczości czy estetyce świadczy obecność w każdej placówce atelier - pracowni plastycznej, studio. Jak podkreślał L. Malaguzzi ,jest to miejsce do manipulowania i prowadzenia doświadczeń wizualnych również w powiązaniu ze słowem" (Gandini 2012b: 41). Ważnym miejscem edukacyjnych doświadczeń dzieci w przedszkolu jest też jadalnia wraz z otwartą kuchnią, która, podobnie jak wszystkie inne miejsca w przedszkolu, jest przestrzenią pozwalającą na dziecięce działania i eksplorowanie. Jak podkreśla Tiziana Filipini

Edukatorzy w Reggio Emilia mówią o przestrzeni jako o kontenerze, który sprzyja społecznym interakcjom, eksploracji i uczeniu się. Przestrzeń postrzegana jest jako mająca edukacyjną ,treść” - jako zawierająca edukacyjny przekaz i naładowana bodźcami dla wzajemnego doświadczania i konstruktywnego uczenia się (Gandini 2012a: 320).

Wyjątkową rolę w przedszkolu pełnią także ściany, które według L. Malaguzziego: „mówią" i dokumentują. Są wykorzystywane do stałych bądź tymczasowych wystaw, ilustrujących proces edukacyjny, mający miejsce w danej placówce (Gandini 2012a). Wystawy zawierają prace dzieci, opinie nauczycieli, opisy i relacje ze zrealizowanych projektów, galerię zdjęć. Przedstawiają przebieg realizowanych w przedszkolu projektów i stają się inspiracją do codziennej komunikacji, refleksji oraz interakcji pomiędzy dziećmi, nauczycielami i rodzicami. Tak zorganizowana przestrzeń stwarza warunki do wspólnego negocjowania znaczeń, a czas spędzony przez dzieci w przedszkolu Reggio Emilia jest bez wątpienia czasem, w którym ich ogromny potencjał ma możliwie najlepsze warunki, żeby się rozwinąćc.

Niniejszy tekst, a w szczególności opis przykładowego dnia w przedszkolu, jest próbą zilustrowania codzienności dzieci w placówkach Reggio Emilia. Opis ten stanowi dla nas z jednej strony swoisty pretekst do przedstawienia fundamentalnych założeń filozofii Reggio, z drugiej zaś stał się inspiracją do namysłu nad ich znaczeniem dla rozwoju dziecięcego potencjału, dla dziecięcego procesu uczenia się.

${ }_{6}$ Przedszkola w Reggio Emilia pracują od poniedziałku do piątku w godzinach od 08:00 do 16:00, w niektórych z nich istnieje możliwość wcześniejszego przybycia (od 07:30) i wydłużonego czasu pracy (do 18:20). 


\section{Dzień w przedszkolu Reggio Emilia ${ }^{7}$}

Szkoła czeka na dzieci, rodziców i pracowników. Wita ich wczesnoporannym światłem, które wpada przez duże okna i z dwóch wewnętrznych dziedzińców. W tym środowisku naturalne światło prowadzi dialog z kolorami i powierzchniami, a przezroczystość podkreśla związek oraz wymianę informacji pomiędzy wnętrzem a zewnętrzem: porą roku, pogodą oraz światłem w różnych porach dnia. Fizyczne środowisko zaprasza i sugeruje dzieciom i ich rodzicom historie, które można tworzyć lub rozwijać (Strozzi 2008: 61).

Godzina 7:30

W placówce pojawia się jeden nauczyciel, który na początku pracy ma pod swoja opieka kilkoro dzieci. Każdy nauczyciel z wyjątkowa wrażliwością i delikatnościa podchodzi do momentu rozstania dziecka z rodzicami. Towarzyszy mu. W przedszkolu nikt nie jest anonimowy. Przedszkole jest miejscem wspólnego przeżywania życia i wymiany doświadczeń.

U podstaw wspólnego przeżywania i doświadczania życia w przedszkolach Reggio leży u m i e jęt n o ść sł u c ha n i a. Interpretowana jest ona nie tylko jako akt biologiczny, ale przede wszystkim jako proces polegający na byciu otwartym i wrażliwym na innych, na ich potrzeby; na akceptowaniu różnic; interpretowaniu; jak również uznawaniu wartości jego nadawcy. Słuchanie pobudza do refleksji i zadawania pytań (Rinaldi 2008). Taka atmosfera wzajemnego szacunku i bezwzględnej akceptacji znaczeń nadawanych przez innych jest warunkiem niezbędnym dla zainicjowania dziecięcego procesu uczenia się.

\section{Godzina 8:00}

Do przedszkola przychodza kolejni nauczyciele: po jednym z każdej grupy. Dzieci rozchodza się do swoich grup, ale wciąż maja możliwość swobodnej aktywności we wszystkich przestrzeniach przedszkola.

Bardzo ważną rolę we wspieraniu rozwoju i aktywności dziecka odgrywa n a u c z yc i e l. Nauczycielskie kompetencje rozpatrywane są w kontekście jego relacji z dziećmi, innymi dorosłymi: współpracownikami i rodzicami, jak również w kontekście jego własnych doświadczeń czy środowiska kulturowego, w którym funkcjonuje (Edwards 2012). Jednym z nadrzędnych zadań nauczyciela jest słuchanie, obserwowanie, rozumienie strategii, jakich używają dzieci w procesie uczenia się. Nauczyciel pełni rolę ,podajnika" okazji, jest źródłem inspiracji, a nie odpowiedzi (Edwards 2012). Pomaga dziecku w znalezieniu problemu, którego rozwiązanie będzie dla dziecka wyzwaniem i przyniesie mu satysfakcję, pomaga odnaleźć jego własne pytania i w naturalny sposób zachęca do szukania odpowiedzi. Celem nauczyciela nie jest takie wspieranie dziecka, aby wszystko szło gładko i łatwo, ale stymulowanie poprzez zwrócenie uwagi na różne aspekty rozwiązywanego problemu. Nauczyciel nie zostawia jednak dziecka samemu sobie, współpracuje z nim nad osiągnięciem jego własnego celu. Niezwykle trudnym zadaniem nauczyciela

\footnotetext{
7 Przykładowy opis dnia przygotowany na podstawie filmu DVD „Everyday Utopias. A day an infant-toddler centre. A day in a preschool" ilustrującego jeden dzień w przedszkolu Diana; prezentacji multimedialnej „Una giornata a scuola” ilustrującej 1 dzień w przedszkolu Bruno Munari oraz notatek autorek.
} 
jest umiejętna i dyskretna interwencja, jeśli dziecko „utknie” czy straci motywację do pracy. Wymaga to nieustannego obserwowania, analizowania i interpretowania jego myślenia, strategii uczenia się. Nauczyciele, którzy z szacunkiem, ciekawością i ze zdumieniem mierzą się z pomysłami, teoriami i hipotezami wysuwanymi przez dziecko, sami uczestniczą w procesie społecznego konstruowania znaczeń (Dahlberg i in. 2013). W tygodniowym czasie pracy nauczyciela, który wynosi 36 godzin, obok 30 godzin przeznaczonych na bezpośrednią pracę z dziećmi, 6 godzin ${ }^{8}$ poświęcanych jest właśnie na szeroko rozumiany rozwój nauczyciela. Dzięki takiej organizacji możliwa jest wspólna praca dwóch pedagogów w tej samej grupie przez kilka godzin dziennie. Takie rozwiązanie daje także szansę na pracę w małych grupach.

\section{Godzina 8:00-9:00}

Większość dzieci przybywa do przedszkola pomiędzy 08:15 a 08:45. Zanim rozpocznie się poranne zgromadzenie, jest czas na swobodna aktywność w różnych zakatkach przedszkola. Dzieci graja w piłkę, tworzą kompozycje na stoliku świetlnym, bawia się w sklep, tworza różnego rodzaju konstrukcje lub bawia się $w$ wewnętrznym ogrodzie. Dzieci, dokonując wyboru aktywności, maja poczucie sprawstwa i wpływu na przestrzeń, w której funkcjonuja. W tym czasie nauczyciel, włączając uczniów w prace, przygotowuje propozycje działań i materiały do wykorzystania $w$ trakcie realizacji projektu.

Grupy, w których dzieci pracują, mają elastyczny charakter, zarówno pod względem ich składu, jak rytmu czy sposobu pracy. Ich struktura zależy od naturalnego biegu wydarzeń i od cech charakterystycznych jej poszczególnych członków. Dzieci, samodzielnie podejmując decyzję, ponoszą współodpowiedzialność za swój własny proces uczenia się. Jednocześnie stają się coraz bardziej jego świadome, o czym świadczyć może poniższa rozmowa 6-latków na temat wyboru grupy:

Caterina: Zwykle chłopcy i dziewczynki nie myślą w inny sposób i mówią raczej w ten sam sposób. Czasami dziewczynki, ponieważ są przyjaciółkami, wybierają siebie; bycie przyjaciółmi jest ważne, to pomaga w grupie. W przeciwnym wypadku dziewczynki czasami nie rozmawiają.

Frederico: W grupie musisz ciężko pracować i, jeśli jesteście przyjaciółmi, pracuje się lepiej. Jeśli popełnisz błąd, nikt nic o tym nie powie i na nowo zaczniecie pracę.

Armando: Bardziej wolę pracować z dziewczynkami, ponieważ są miłe; grzecznie rozmawiają, nie są głośne. (Vecchi 2008: 168-167).

Także dbałość o odpowiednie zorganizowanie przestrzeni edukacyjnej wynika z chęci respektowania założeń społecznego konstrukcjonizmu. Struktura, wybór materiałów i ich atrakcyjny sposób wyeksponowania mają być otwartym zaproszeniem do działania i eksplorowania. Wszystko jest uważnie i celowo dobrane i umiejscowione w celu pobudza-

86 godzin $(2,5 \mathrm{~h}$ - spotkania całego zespołu, 1 h rozwój zawodowy, 1 h spotkania z rodzicami, 1,5 h przygotowywanie materiałów i dokumentacji). 
nia komunikacji i zachęcania do używania różnych języków. Nauczyciel angażuje dzieci w przygotowanie materiałów. Takie działanie nie tylko ułatwia organizację, ale przede wszystkim jest częścią projektu. Wzbudza w dzieciach ciekawość i zainteresowanie. Zaintrygowane, oczekują chwili, w której dane materiały zostaną wykorzystane w projekcie.

\section{Godzina 8:30}

Do przedszkola przychodzi drugi nauczyciel z każdej grupy. Wita się z dziećmi i kolegami. Podczas gdy jeden z nauczycieli towarzyszy dzieciom, drugi ma szansę na spokojna rozmowę z rodzicami.

W każdej klasie pracuje równocześnie dwóch nauczycieli o zróżnicowanym stażu pracy. Pracując razem przez cały dzień, nauczyciele dyskutują i konsultują się ze sobą, co ma znaczący wpływ na rozwój zarówno młodego stażem nauczyciela, jak i tego bardziej doświadczonego. Dzięki takiej organizacji stworzona zostaje przestrzeń do wymiany spostrzeżeń, stawiania pytań, wspólnego poszukiwania odpowiedzi i przedstawiania różnych punktów widzenia tej samej sytuacji. Współpraca nauczycieli jest widoczna dla dzieci i tym samym staje się dla nich przykładem.

\section{Godzina 8:45}

Dzieci porządkuja przestrzeń, przygotowując salę do porannego zgromadzenia. Same decyduja, które materiaty sprzątnać, a które pozostawić, ponieważ $w$ dalszej części dnia będa jeszcze wykorzystywane podczas pracy w malych grupach.

\section{Godzina 9:00}

Po owocowym poczęstunku rozpoczyna się jeden z najważniejszych momentów w ciagu dnia - poranne zgromadzenie petniace role przedszkolnego forum i będace miejscem demokratycznie podejmowanych decyzji. To czas na wymianę i negocjowanie pomystów. Nawiazując do wcześniejszych wydarzeń w projekcie, dzieci ustalaja, co będa robić dalej. To właśnie w trakcie obrad ,"dziecięcego parlamentu” ich doświadczenia i przeżycia staja się inspiracja do podjęcia kolejnych działań i rozpoczęcia nowego projektu. Jednym z takich doświadczeń byly narodziny siostry jednego z chtopców. Zainicjowało ono dyskusję na temat narodzin i dorastania.

Matteo: Urodziłem się w brzuchu mamy i byłem taki maly.

Diego: Kiedy ja się urodziłem bytem mały, taki mały jak mrówka i mieścitem się w dtoni... Później rostem i rostem, i statem się duży, bo pitem dużo mleka.

Giulia: Ja bytam malutka i bytam w brzuchu mamy i zawsze mocno kopałam.

Omar: Ja kiedy się urodziłem nie miałem jeszcze imienia, bo nie wiedzieli jak mnie nazwać... Późnej, jak urostem nazwali mnie Omar!

N-lka: Zanim pojawiliśmy się tutaj, gdzie byliśmy? 
Diego: Byliśmy w myślach mamy i taty, którzy nie wiedzieli jak mnie nazwać, ponieważ mnie jeszcze nie było i nie można nazwać dziecka, kiedy jest w niebie! Jak wyszedłem na zewnątrz, nazwali mnie Diego.

Giulia: W rodzinach czujemy się dobrze, bo sa mamy, które nas kochają! Moja mama, jak się urodziłam, była szczęśliwa i później mnie wzięła na ręce, bo nie umiałam chodzić.

Emilio: Dzieci chca się narodzić i chca zobaczyć swoje mamy i tatów, i braci! Mamy też się narodzity!

Bianca: Pochodza od innych mam: urodziły się przed nimi i później rodza dzieci, i później staty się babciami.

Omar: Mamy najpierw rodza dziewczynki, a później stają się mamami.

Emilio: ... mamy mogą wyjaśnić ci dużo rzeczy, bo ich mamy im wyjaśniały.

Gabriele: Mamy myślą o pięknych rzeczach, jak myślą o rzeczach złych to się przestraszają!

Bianca: Myśla, że nas kochaja.../ Myśla, żeby nas kochać... (Una giornata a scuola, b.d.) ${ }^{9}$

Po skończonej rozmowie, dla zilustrowania swoich pomystów i interpretacji dzieci wykonaly graficzne reprezentacje mamy $w$ ciązy.

Konstruowanie wiedzy jest procesem społecznym, tak więc wyrażenie potencjału dziecka możliwe jest tylko w kontekście grupowego uczenia się. Każda osoba jest inspirowana teoriami, hipotezami innych. Konfrontacje pozwalają na tworzenie własnych teorii, wyciąganie wniosków, a wchodzenie w interakcje z innymi daje dzieciom możliwość przeformułowania początkowych założeń. Jest to przykład procesu asymilacji i akomodacji w grupie (Rinaldi 1998). Dziecięce rozmowy są niejednokrotnie źródłem inspiracji dla realizowanych w przedszkolach Reggio projektów. Na podstawie dziecięcych wspomnień i przemyśleń nauczyciele są w stanie formułować hipotezy na temat tego, co może wydarzyć się na dalszych etapach projektu. W placówkach Reggio Emilia nauczyciele nie ustalają programu $\mathrm{z}$ wyprzedzeniem. Jest on elastyczny i wynika z osobistych doświadczeń dzieci i nauczycieli. Jest realizowany w postaci krótko lub długotrwałych projektów. Dla określenia takiego sposobu pracy włoscy pedagodzy używają pojęcia prog e t ta zi o ne (zob. Maj 2014). W koncepcji tej planowanie pracy przez nauczyciela rozumiane jest jako przygotowanie i organizowanie przestrzeni i materiałów, stwarzanie sytuacji czy prowokowanie. Planowanie nie jest zakończonym procesem, nieustannie jest w toku i ma charakter ciągły. Projekt może ewoluować, nie ma terminarza czy harmonogramu działań. C. Rinaldi koncepcje planowania występującą w placówkach Reggio porównuje do podróżowania $\mathrm{z}$ kompasem, w przeciwieństwie do podróżowania pociągiem, po ustalonej trasie i zgodnie z rozkładem jazdy (Rinaldi 1998).

Godzina 9:45-10:45

9 Tłumaczenia z języka włoskiego dokonała Patrycja Wójcik. 
Dzieci pracuja w malych grupach, wykonując zadania ustalone podczas porannego zgromadzenia. Niektóre z dzieci postanawiaja kontynuować prace rozpoczęta z samego rana. Jedna z grup pracuje $z$ atelierista $w$ atelier.

W 25-osobowej klasie jest zwykle 6 grup, których liczebność i skład ulegają zmianom. Grupy pracują jednocześnie, w swoim własnym tempie i rytmie. Dla każdej z grup nauczyciel stawia hipotezy, jedne grupy pracują z nauczycielem, a inne samodzielnie. Gdy wszystkie grupy zakończą pracę, spotykają się ponownie, aby podsumować i skomentować swoją pracę. Dotyczy to nie tylko uzyskanych rezultatów, ale także samego procesu tworzenia. Ma wówczas miejsce tzw. proces przywoływania (revisiting), który możliwy jest tylko przy udziale innych - zarówno dzieci, jak i dorosłych. Polega on na odtwarzaniu swojej dotychczasowej doświadczeń, m.in. na podstawie dokumentacji. W kolejnych dniach, na ich podstawie, wyłaniają się nowe pomysły i propozycje działań, będące wypadkową wspólnych doświadczeń wszystkich członków grupy (Forman 2005). Według edukatorów Reggio Emilia:

Gdy mówimy o grupowym uczeniu się, można błędnie zrozumieć, że pojawia się ono tylko wtedy, gdy grupa współpracuje nad stworzeniem tego samego wytworu. Naszym zdaniem grupowe uczenie się ma miejsce również wtedy, gdy proces i rezultat mają charakter indywidualny, ale generowane są i tworzone w ramach sieci relacji, samooceny i oceny dokonywanej przez grupę i w grupie (Vecchi 2008: 188).

Strategia pracy w małych grupach jest więc naturalną konsekwencją, przyjętych w Reggio, teoretycznych założeń związanych z procesem społecznego/kolektywnego konstruowania wiedzy.

\section{Godzina 10:45-11:40}

Dzieci spędzaja czas na świeżym powietrzu. Bawia się, graja w gry zespolowe, tworzq kompozycje z naturalnych materiałów. Dzieci, petniące obowiązi kelnera, pomagaja w kuchni i nakrywaja do stotów.

Wspólne przygotowywanie posiłków jest doskonałą okazją do kontaktu i budowania relacji z innymi pracownikami przedszkola. Wszyscy zatrudnieni w przedszkolach Reggio pracownicy ${ }^{10}$ tworzą zespół, w którym jako partnerzy wspólnie pracują nad stworzeniem dzieciom jak najlepszych warunków rozwoju. C. Rinaldi, wspominając jedno ze spotkań poświęconych teorii pedagogicznej, w której uczestniczyli wszyscy pracownicy, w tym także personel pomocniczy, zwróciła szczególną uwagę na znaczenie różnych perspektyw w tworzeniu projektu edukacyjnego.

\footnotetext{
${ }^{10}$ Przykładowo w przedszkolu, do którego uczęszcza 78 dzieci, zatrudnionych jest 6 nauczycieli na pełen etat i 1 na pół etatu (placówka o wydłużonym czasie pracy), 1 atelierista, 2 kucharzy (1 na cały i 1 na pół etatu), 3 pomoce na pół etatu oraz 1 pedagogista (ulotka z przedszkola 2009), który pod swoją opieką ma kilka placówek (w przedszkolach Reggio Emilia nie ma dyrektora).
} 
Szczególnie zapamiętałam cenne spostrzeżenia, jakimi podzielił się z nami personel pomocniczy. Być może ich źródłem jest, oparta na odmiennych doświadczeniach, zdolność słuchania dzieci: innymi uszami, pod innym kątem oraz w odmiennej przestrzeni, pełnej intymności, ponieważ to właśnie te osoby dzielą z dziećmi takie sytuacje, jak pójście do toalety (Rinald 2006b: 150).

Spotkania pracowników przedszkoli w Reggio nie polegają więc na narzucenia reguł z zewnątrz, przez uznawanych za bardziej kompetentnych członków zespołu, ale jako wspólne doświadczanie, dzielenie się i negocjowanie znaczeń.

\section{Godzina 12:00}

Czas na obiad jest czasem nie tylko na positek, ale także okazja do budowania relacji pomiędzy dziećmi.

Dzieci pomagają sobie w nakładaniu na talerze porcji potraw. Poznając swoje preferencje i upodobania kulinarne, lepiej poznają siebie. Dostrzegają różnice i rozmawiają o nich. Czas wspólnego posiłku jest też czasem rozmów miedzy dziećmi. Rozmowa jest niezwykle ważna również dla 5-letniego Lorenzo, który tak oto ją rozumie:

Nazywam to mostem słów, ponieważ słowa idą z jednej buzi do drugiej; ja mówię do niego, on mówi do mnie. Most słów oznacza, że poznajemy dzieci, których nie znamy, sprawia, że się zaprzyjaźniamy, czasami, jeśli słowa nie są miłe, powodują kłótnie (The Charter...2005: 35).

\section{Godzina 12:45-15:00}

Dzieci przygotowuja się do snu. Nauczyciel przystosowuje przestrzeń. Zastania okna, puszcza spokojna, relaksująca muzykę lub czyta ksiażkę. Większość dzieci zasypia, te, które nie chca, moga w ciszy pracować z nauczycielem w mini atelier. W czasie drzemki dzieci nauczyciele maja lunch. Jest to dla nich okazja do omówienia przebiegu dnia, do wspólnej refleksji. Nauczyciele wykorzystuja ten czas także na przygotowanie dokumentacji.

Jednym z firmowych znaków Reggio Emilia jest sposób, w jaki dokumentowana jest praca dzieci i nauczycieli. To, w jaki sposób placówki Reggio podchodzą do d o k u m e nt a c j i, jest niezwykle nowatorskim rozwiązaniem, którego celem jest pokazanie natury procesu uczenia się oraz strategii używanych przez poszczególne dzieci. Według C. Rinaldi dokumentacja jest nie tylko namacalną kolekcją dowodów tego, co działo się w klasie: wytworów dziecięcych, płyt, kaset video, slajdów, ale przede wszystkim jest procesem ich zbierania, poddawania refleksji oraz wspólnej interpretacji. Dokumentacja stanowi narzędzie oceny i ewaluacji, wykorzystywana jest w planowaniu działań edukacyjnych, stanowi podstawę rozwoju zawodowego nauczycieli oraz odgrywa istotną rolę w kreowaniu przedszkola jako miejsca, w którym naczelna zasadą działania jest demokracja (zob. Maj 2013). Poprzez dokumentację placówki tworzą potężną spuściznę pracy możliwej do zobaczenia. Dokumentacja pracy dzieci jest jednocześnie dokumentacją nauczycielskich wizji, pomysłów, wiedzy. Wydobywa i pozwala zinterpretować sposób myślenia osoby dokumentującej. Zdradza subiektywizm dokumentatora, a jednocześnie otwiera pole do 
interpretacji dla innych osób. Dzięki temu jest interesująca i gromadzi wielu odbiorców (Rinaldi 2006b).

Jeśli nauczanie oznacza ułatwianie uczenia się, organizowanie dziecku sytuacji i kontekstów uczenia się, to sytuacje te i konteksty mogą być tworzone tylko wtedy, gdy sposoby uczenie się dzieci są zwizualizowane. Dokumentacja dostarcza większej pewności, że jesteśmy blisko dzieci nie tylko fizycznie, ale że jesteśmy blisko ich procesu uczenia się; i w ten sposób uczymy się nauczać. Te ślady, wspomnienia, dokumenty są wykorzystywane jako materialny dowód, ale ponieważ próbujemy je interpretować, odpowiedzieć na pytanie „dlaczego” i szukać tego, „co robić”, są one także przedmiotem indywidualnej i grupowej refleksji, rozwoju zawodowego czy samodoskonalenia się nauczycieli (Rinaldi 2006a: 114).

Dokumentacja spełnia więc wiele funkcji i ważna jest zarówno dla dzieci, rodziców, jak i nauczycieli:

- dla dzieci, aby pokazać, że ich wysiłek jest wartościowy, aby mogły odnieść się do swojej pracy, spojrzeć na siebie z zewnątrz, ale także poznać i odnieść się do pracy kolegów,

- dla nauczycieli, którzy dzięki dokumentacji mogą przeanalizować pracę dzieci i lepiej zrozumieć dziecięcy proces uczenia się oraz zaplanować następne etapy procesu dydaktycznego,

- dla rodziców, aby mogli poznać i zrozumieć doświadczenia i prace swoich dzieci. Poza tym dokumentacja jest źródłem wiedzy dla społeczności lokalnej o działaniach podejmowanych w placówkach edukacyjnych; tworzy historię instytucji, historię procesu edukacji (Wurm 2005).

\section{Godzina 15:00}

Dzieci budza się ze snu. To wyjątkowy moment. Nikt się nie spieszy, nie pogania. Na koniec dnia dzieci otrzymuja podwieczorek.

Przedszkola Reggio Emilia są miejscem życia, a nie fabryką, w związku z tym wymagają czasu życia, a nie czasu produkcji. Nie produkt, a proces jest istotą dziecięcego działania. Czas jest niezbędny przy odkrywaniu, budowaniu relacji, przy czym każde dziecko odkrywa, nawiązuje relacje i komunikuje się w swoim własnym tempie, który każdy nauczyciel w przedszkolu Reggio respektuje i uwzględnia w codziennej pracy. Jak zaznacza C. Rinaldi: „Nie chodzi o rywalizację między szybkością a powolnością, ale o posiadanie odwagi do ponownego odkrywania czasu ludzkiego" (Rinaldi 2006b: 207).

\section{Godzina 15:30-16:00}

Dzieci odbierane sa z przedszkola przez rodziców. To czas nie tylko na porozmawianie z nauczycielem o minionym dniu, ale również na spędzenia wspólnych chwil w przedszkolnym ogrodzie.

R o d z i n a jest jedną z podstawowych wartości we włoskiej kulturze. Poczucie przynależności i budowanie więzi rodzinnych jest niezwykle silne, nic więc dziwnego, że re- 
lacja szkoła-rodzice jest istotnym elementem praktyki edukacyjnej w placówkach Reggio i określana jest ona terminem p a r t y c y p a c j i (partezipazione). Oznacza to, że zarówno dzieci, nauczyciele, jak i rodzice są zaangażowani w aktywność przedszkola i uczestniczą w jego życiu na równych prawach. Zamiast podkreślania różnic, w placówkach Reggio propagowany jest dialog międzykulturowy, wymiana idei i pomysłów. Szkoła oparta na uczestnictwie, współdziałaniu to miejsce, w którym każdy ma prawo mówić i być wysłuchanym. C. Rinaldi rozumie partycypację jako strategię edukacyjną, która charakteryzuje istotę działania placówek Reggio (Rinaldi 2008). Współpraca polega nie tyle na samym uczestnictwie rodziców w życiu placówki, ale na byciu jego częścią, nieodzownym elementem funkcjonowania przedszkola. Rodzic postrzegany jest jako kompetentny uczestnik procesu edukacji. Zaangażowanie i udział rodziców jest wartością, która identyfikuje proces edukacyjny. Doświadczają jej również same dzieci.

Mamusie i tatusiowie też przychodzą do przedszkola, mają spotkania z wszystkimi pozostałymi tatusiami i mamusiami, siedzą na krzesłach i mówią same ważne rzeczy (...) rozmawiają o nas (...) przychodzą, żeby się dowiedzieć, co robią ich dzieci.

Mamy też ze sobą rozmawiają, może rozmawiają o swoich dzieciach. Przychodzą zobaczyć, jakie fajne rzeczy tworzymy (...) nasze arcydzieła!

Nauczyciele wyjaśniają rodzicom różne sprawy, a rodzicie wyjaśniają różne sprawy nauczycielom... w taki sposób robi się spotkanie (The Charter... 2005).

Kontakty z rodzicami mogą przybierać najróżniejsze formy. Należą do nich:

- czerwcowe spotkania dla rodziców, których dzieci od nowego roku szkolnego uczęszczać będą do przedszkola; są one okazją do poznania nauczycieli oraz całego zespołu;

- rozmowy z rodzicami na kilka dni przed przyjściem dziecka po raz pierwszy do przedszkola, poświęcone ustaleniu zasad funkcjonowania dziecka w pierwszych dniach pobytu w przedszkolu;

- w pierwszych dniach rodzice uczestniczą w zajęciach razem z dzieckiem, zasady obecności rodziców ustalane są indywidualnie z każdą rodziną;

- spotkania z rodzicami, mające na celu gromadzenie pomysłów do pracy w ciągu roku czy przedstawienie stosowanych w placówkach metod; spotkania tematyczne, w których uczestniczą nauczyciele i rodzice zainteresowani dyskusją na konkretne tematy np. rola taty w życiu przedszkolaka; spotkanie może być zainicjowane przez każdego nauczyciela, członka zespołu czy rodzica;

- otwarte spotkania z ekspertami, które mają formę wykładów czy dyskusji, mogą obejmować rodziców dzieci z różnych przedszkoli;

- spotkania inicjowane i prowadzone przez rodziców, rodzice pełniący rolę gospodarza inicjują i proponują temat spotkania; takie spotkania są forum wymiany poglądów, doświadczeń pomiędzy rodzicami; nauczyciel jest zaproszony i uczestniczy w spotkaniu; 
- working session - wieczorne spotkania, podczas których pracownicy, rodzice, jak również inni członkowie rodziny, np. dziadkowie, wujkowie pracują nad realizowanym projektem;

- warsztaty, podczas których rodzice zdobywają umiejętności z zakresu np. malowania, wykorzystania papieru, tworzenia kukiełek; odmianą tego rodzaju spotkań są tzw. wieczory w kuchni, podczas których rodzice gotują wraz z dziećmi potrawy z przedszkolnego menu; niezwykle przyjemnym i integrującym elementem jest wspólny posiłek;

- organizacja imprez okolicznościowych, w których uczestniczą nie tylko najbliżsi dzieci, ale również członkowie środowiska lokalnego;

- pikniki, wycieczki (Rinaldi 2006b).

Przedstawiony powyżej typowy dzień w przedszkolu Reggio Emilia pozwala dostrzec zróżnicowane formy aktywności wszystkich uczestników procesu edukacyjnego: dzieci, nauczycieli oraz rodziców i opiekunów. Charakter podejmowanych działań dowodzi tego, iż są one świadomie i konsekwentnie tworzone i realizowane dla wspierania wszechstronnego rozwoju dzieci, dla rozwijania ich potencjału.

\section{Zakończenie}

Mamy nadzieję, że przedstawione w tekście założenia teoretyczne oraz przykładowy dzień w przedszkolu w Reggio Emilia pozwolą dostrzec w tych placówkach sprzyjające dla rozwoju dziecięcego potencjału warunki uczenia się. Dotyczą one nauczyciela budującego rusztowanie dla uczenia się poprzez negocjowanie z innymi uczestnikami procesu a także całej przestrzeni edukacyjnej. Są one efektem inspiracji czerpanych przez pedagogów nie tylko z pedagogiki i psychologii, ale także z filozofii, architektury, literatury czy komunikacji wizualnej. Wynikają z ciekawości nauczycieli oraz ich gotowości do przekraczania granic, otwartości na nowe perspektywy. Czerpanie inspiracji oznacza tu również krytycyzm i dociekliwość, dzięki którym poznawane teorie nie są reprodukowane, a interpretowane i stają się zaczynem dla tworzenia własnej wizji środowiska edukacyjnego.

\section{Literatura}

Bonar J. (2011) Kreatywny czyli inny. Twórczy uczeń w polskiej szkole. W: I. Chrzanowska, B. Jachimczak, D. Podgórska-Jachnik (red.), Miejsce innego we wspótczesnych naukach o wychowaniu. Inny wobec wyzwań współczesnego świata. Łódź, Wydawnictwo Naukowe WSP.

Bruner J. (2012), Preface: Reggio: A City of Courtesy, Curiosity, and Imagintaion. W: C. Edwards, G. Forman, L. Gandini (red.), The Hundred Languages of Children. The Reggio Emilia Experience in Transformation. Santa Barbara, Praeger.

Cadwell L. (2003), Bringing Learning to Life. New York, Teachers College Press.

Dahlberg G., Moss P., Pence A. (2013), Poza dyskursem jakości w instytucjach wczesnej edukacji i opieki. Wrocław, Wyd. Nauk. DSW. 
Edwards C. (2102), Teacher and Learner, Partner and Guide. W: C. Edwards, G. Forman, L. Gandini (red.), The Hundred Languages of Children. The Reggio Emilia Experience in Transformation. Santa Barbara, Praeger.

Everyday Utopias. A day an infant-toddler centre. A day in a preschool (2013), [DVD].

Filipini T., Vecchi V. (red.) (2006), The Hundred Languages of Children. Reggio Emilia, Reggio Children srl.

Forman G. (2005), The Project Approach in Reggio Emilia. W: C.T. Fosnot (red.), Constructivism: Theory, Perspectives, and Practice. New York, Teachers College Press.

Forman G., Gandini L. (1994), The amusement park for birds [kaseta VIDEO]. Performanetics, 19 The Hollow, Amherst, MA01002.

Gandini L. (2012a), Connecting through Caring and Learning Spaces. W: C. Edwards, G. Forman, L. Gandini (red.), The Hundred Languages of Children. The Reggio Emilia Experience in Transformation. Santa Barbara, Praeger.

Gandini L. (2012b), History, Ideas, and Basic Principles: An Interview with Loris Malaguzzi. W: C. Edwards, G. Forman, L. Gandini (red.), The Hundred Languages of Children. The Reggio Emilia Experience in Transformation. Santa Barbara, Praeger.

Gardner H. (2008), Introductions. W: C. Giudici, M. Krechevsky, C. Rinaldi (red.), Making Learning Visible: Children as Individual and Group Learners. Reggio Emilia, Reggio Children srl.

Gardner H. (2012), Foreword. W: C. Edwards, G. Forman, L. Gandini (red.), The Hundred Languages of Children. The Reggio Emilia Experience in Transformation. Santa Barbara, Praeger.

Hinckle P. (1991). A school must rest on the idea that all children are different (early childhood education in Reggio Emilia, Italy) (The Best Schools in the World). "Newsweek" v 118, nr 23.

Maj A. (2013), Dokumentowanie procesu edukacyjnego jako fundament pracy nauczyciela wczesnej edukacji - z doświadczeń nauczycieli przedszkoli w Reggio Emilia we Włoszech. W: J. Bonar, A. Buła (red.), Poznać. Zrozumieć. Doświadczyć. Konstruowanie wiedzy nauczyciela wczesnej edukacji. Kraków, Oficyna Wydawnicza Impuls.

Maj A. (2014), Metoda projektów we wczesnej edukacji szansq demokratyzacji przestrzeni edukacyjnej dziecka. W: K. Gawlicz, P. Rudnicki, M. Starnawski, T. Tokarz (red.), Demokracja i edukacja: dylematy, diagnozy, doświadczenia. Wrocław, Wydawnictwo Naukowe Dolnośląskiej Szkoły Wyższej.

Malaguzzi L., Your Image of the Child: Where Teaching Begins. Child Care Information Exchange No 96/1994.

Rinaldi C. (1998), Projected Curriculum and Documentation. W: C. Edwards, L. Gandini, G. Forman (red.), The Hundred Languages of Children: The Reggio Emilia Approach - Advanced Reflections. Norwich, CT, Ablex Publishing.

Rinaldi C. (2006a), 1980-1996: The evolution of the choice. W: T. Filipini, V. Vecchi (red.), The Hundred Languages of Children. Reggio Emilia, Reggio Children srl.

Rinaldi C. (2006b), In Dialogue with Reggio Emilia. Listening, Researching and Learning. London, Routledge.

Rinaldi C. (2008), Infant-toddler Centere and Preschools as Places of Culture. W: C. Giudici, M. Krechevsky, C. Rinaldi (red.), Making Learning Visible: Children as Individual and Group Learners. Reggio Emilia, Reggio Children srl.

Strozzi P. (2008), Daily Life at School: Seeing the Extraordinary in the Ordinary. W: C. Giudici, M. Krechevsky, C. Rinaldi (red.), Making Learning Visible: Children as Individual and Group Learners. Reggio Emilia, Reggio Children srl. 
The Charter of The City and Childhood Councils by the Study Group on "Identities and Functions of The City and Childhood Councils" (2005), Reggio Emilia, Reggio Children srl.

Una giornata a scuola. Scuola Comunale dell'Infanza BRUNO MUNARI. Reggio Emilia. [Prezentacja multimedialna].

Vecchi V. (2008), The Couriosity to Understand. W: C. Giudici, M. Krechevsky, C. Rinaldi (red.), Making Learning Visible: Children as Individual and Group Learners. Reggio Emilia, Reggio Children srl.

Wurm J.P. (2005), Working in the Reggio Way. A Beginner's Guide for American Teachers. St. Paul, MN, Redleaf Press. 